\title{
MERRE VAN AZ ELŐRE? \\ INNOVÁCIÓS FOLYAMATOK MEGJELENÉSE A DUNÁNTÚLI MEZŐGAZDASÁGI VÁLLALKOZÁSOKNÁL
}

\section{ATTITUDE TOWARDS NEW DEVELOPMENTS AMONG TRANSDANUBIAN AGRICULTURAL ENTREPRENEURS}

\author{
Göllény-Kovács Nikoletta ${ }^{1,4}$, Péter Erzsébet ${ }^{2,4}$, Németh Kornél ${ }^{3,4}$ \\ 1PhD-hallgató \\ nikoletti.kovacs@gmail.com \\ 2egyetemi docens \\ peter.erzsebet@uni-pen.hu \\ 3egyetemi docens \\ nemeth.kornel@uni-pen.hu \\ ${ }^{4}$ Pannon Egyetem Nagykanizsai Kampusz, Nagykanizsa
}

\begin{abstract}
ÖSSZEFOGLALÁS
Kutatásunkat a mezőgazdasági vállalkozók körében végeztük, mivel az ágazat esetében kiemelten magas költségekkel és kockázatokkal lehet számolni. A tanulmány készítése során arra voltunk kíváncsiak, hogy a dunántúli mezőgazdasági vállalkozók hogyan vélekednek az újításokról, fejlesztésekről. Mennyire nyitottak a gazdák az új fejlesztések iránt, illetve mi befolyásolja leginkább a lehetőségek kihasználásának aktivitását. A szakirodalmi áttekintés alapján azt feltételezzük, hogy a fejlett technológiával rendelkező mezőgazdasági vállalkozók nyitottabbak az új fejlesztésekre, mint a kevésbé fejlett társaik, mivel ők azok, akik eddig is több figyelmet fordítottak az innovációra, tudásra. További hipotézisünk szerint a magasabb iskolai végzettséggel rendelkező mezőgazdasági vállalkozók nyitottabbak az új fejlesztésekre, mint társaik. Az eredményeink alapján innovatív gazdálkodók nagy része tőkeerős, mégis minél fejlettebb a technológia, és minél magasabb a végzettsége adott dunántúli mezőgazdasági vállalkozónak, annál kevésbé próbálja ki az új fejlesztéseket. Az új technológiákban magasabb kockázatot látnak a magasabb iskolai végzettséggel rendelkező válaszadóink, mivel kevésbé tudják felmérni az esélyeiket, és látszólag inkább a kockázatkerülő magatartást választják. Inkább megelégszenek a kevesebb, de biztosabb jövedelemmel, mint hogy a kockázatvállaló magatartás felé haladjanak.
\end{abstract}

\section{ABSTRACT}

Our research was conducted among agricultural entrepreneurs, because of the extremely high costs and risks of the sector. We were eager to learn preparing the dissertation how agricultural entrepreneurs in the Western, the more developed part of Hungary think about innovations and developments. How open farmers are to new developments, and what is the most influential 
element in their activities of exploiting opportunities. Based on the literature reviews, we assume that farmers with advanced technology are more open to new developments than their less developed counterparts, as they have been already more focused on innovation and knowledge. We also assumed that farmers with higher education qualifications are more open to new developments. According to our results, the majority of innovative farmers are capitalintensive, yet the more advanced the technology and the higher the qualification of a given Transdanubian agricultural entrepreneur, the less they try new developments. Respondents with a higher educational level see higher risks in new technologies because they are less able to assess their chances and appear to prefer risk-averse behavior. They are content to go for less but more secure income than for risk-taking behavior.

Kulcsszavak: tudás, elégedettség, fejlődés, mezőgazdaság, vállalkozások

Keywords: knowledge, satisfaction, development, agriculture, entrepreneurs

\section{BEVEZETÉS}

Az innováció elméleti alapjai legelőször Joseph A. Schumpeter 1934-es tanulmányában jelentek meg, aminek nyomán ma az innovációnak különböző típusait különböztethetjük meg. Innováció alatt értjük például egy új termék bevezetését, egy új gyártási mód bevezetését, új piac megnyitását, új nyersanyag megszerzését, iparági átszervezést. Schumpeter tanulmánya alapján sok elgondolás született az innovációval kapcsolatban, azonban minden esetben egy új ötletből, kreativitásból, alkotóerőből indul ki az innovációs folyamat, amelynek eredményeként a napi gyakorlatban alkalmazott termék keletkezik. A regionális innovációs kultúra kulcsfontosságú elméleteit Péter 2018-as munkájából is megismerhetjük, melyben arra a tényre is rávilágít, miszerint a régió és az üzleti világ közti kapcsolat ritkán egydimenziós. Számos olyan egymásba fonódó terület létezik, amelyekben a helyi, a regionális, a kormányzati és a vállalati intézmények formális és informális kommunikációja zajlik (Péter, 2018).

Az innovációs folyamatok a vállalkozások esetében fejlődést, továbblépést jelentenek, ugyanakkor magas kockázattal és költségekkel is járhatnak (Birkner, 2017; Kontor, 2017). Kutatásunkat a továbbiakban mezőgazdasági vállalkozók körére szükítenénk tovább, mivel az ágazat esetében kiemelten magas költségekkel és kockázatokkal lehet számolni. Egy 2017-es felmérés szerint a megújulás terén például a gazdálkodók három különböző csoportba sorolhatók, aszerint, hogy hogyan kezelik az új információs technológiákat. A három csoportot analitikusként, információhalmozóként és izoláltként jelölték a szerzők, ami nem jelent mást, mint az első csoportként emlegetett innovatív gazdákat (38\%), a második csoportba tartozó, a technikát mérsékelten adaptáló gazdákat (26\%), illetve a harmadik csoportra jellemző erőforrásszegény gaz- 
dákat (36\%) (Csótó, 2017). A kutatás eredménye szerint körülbelül ugyanannyi az erőforrásszegény gazda, mint az innovatív, ami megosztja a gazdálkodók lehetőségeit.

Az erőforrásszegény gazdálkodás leginkább azért emlegethető problémaként, mivel az informatikai változások a mezögazdaságban használt eszközöket sem kerülték el, és a fejlődés követésében hazánk elmaradást mutat (Berta, 2018). Ez egyrészt, fejlödési potenciált jelent a jövőben, másrészt, ha nem veszik komolyan a gazdálkodók az informatikai eszközök használata terén éleződő versenyt, akkor komoly lemaradással számolhatunk.

Kutatásunk során arra voltunk kíváncsiak, hogy a dunántúli mezőgazdasági vállalkozók hogyan vélekednek az újításokról, fejlesztésekröl. Mennyire nyitottak a gazdák az új fejlesztések iránt, illetve mi befolyásolja leginkább a lehetőségek kihasználásának aktivitását.

\section{SZAKIRODALMI ÁTTEKINTÉS}

Az innovációs folyamat általában az egyéni ötletgenerálással kezdődik, amit az ötlet végrehajtása követ a csapat vagy szervezet szintjén a későbbi szakaszokban (Lukes-Stephan, 2017). Ugyanakkor az innovációs folyamatok bonyolultak, és sokrétü viselkedést igényelnek, mint például az ötlet kommunikációja az érdekeltek bevonásával, valamint a kreatív ötletek innovációként való megvalósítását nehezítő akadályok leküzdése (Sarooghi et al., 2015). Kazainé Ónodi Annamária és Kiss János közös, 2018-as hazai kutatásukban kimutatták, hogy a hazai tulajdonú vállalatok elsősorban az adóztatást, a túlzott bürokráciát és a pénzügyi források hiányát jelölték meg innovációs akadályként. Továbbá kutatásukból az is kiderült, hogy a magyar tulajdonú vállalatoknak lenne mit tanulniuk a külföldi tulajdonú vállalatoktól az alkalmazottak innovációs ötleteinek támogatása, és az innovációs tevékenység korszerü informatikai eszközökkel és szervezeti megoldásokkal való segítése terén.

Az információ és ötletgenerálás elengedhetetlen része az innovációs folyamatoknak, a fejlődésnek, azonban mindez csupán kiegészítésként szolgál a tudás mellett. Amennyiben a mezőgazdasági termelésre szükítjük elemzésünket, Nótári Márta és munkatársai 2013-as kutatása alapján elmondható, hogy a mezögazdasági foglalkoztatottak végzettségi szintje annak ellenére nagyon alacsony hazánkban, hogy az alátámasztott tény alapján a magasabb végzettségi szinttel rendelkező alkalmazottak társaiknál hatékonyabb munkát képesek végezni.

A tudás azonban nem csupán a hatékony munkavégzés és fejlődés alapja, hanem a vállalkozás fenntartásában is szerepet játszik. A hosszú távú fenntartásnak elengedhetetlen részét képezi az a folyamat, amikor generációváltás során szükségessé válik a vállalkozás átörökítése. Ez a folyamat elsőre jelentéktelennek tủnhet 
müködő vállalkozás révén, azonban a tapasztalatok azt mutatják, hogy tudás hiányában kudarcba fulladhat (Noszkay, 2017). Ezen veszteségek kiküszöbölhetők lennének, amennyiben az érintettek megfelelö felkészültséggel rendelkeznének, vagy segítséget kérnének az ezen tudás birtokában lévőktől.

Mivel a vállalkozói lét egy rendkívül bizonytalan folyamat, magas stresszhatással és félelemmel járhat (McMullen-Shepherd, 2006). Ugyanakkor sokan arról számoltak be új vállalkozásuk indítása után, hogy elégedettebbek új munkájukkal és életükkel, annak ellenére, hogy kevesebbet keresnek és/vagy többet dolgoznak (Benz-Frey, 2008a, 2008b). Sokan a vállalkozást mint önfoglalkoztatást definiálják, annak ellenére, hogy az önfoglalkoztatás fogalma nagyban különbözik a vállalkozói feladatok iránti elköteleződéstől (Parker, 2004). A vállalkozói feladatok iránti aktív elköteleződés esetében ugyanis kiemelhető a tanulás fontossága, mivel ez nem köthető a foglalkoztatáshoz, sokkal inkább az egyéni célok eléréséhez, ami az alapvető pszichológiai igények kielégítése esetében kritikus része lehet az elégedettség érzésének (Shir et al., 2018). Külön kiemelendő tehát a vállalkozói elégedettség szempontjából a tudás megszerzésének öröme, mely egyben a vállalkozás motorjaként is szolgál.

Azt is kimutatták, hogy az igazán hatékony KKV-k több figyelmet fordítanak az információkra, tudásra és innovációra, mivel szinte kizárólag ezzel tudják növelni teljesítményüket és profitjukat (Keskin, 2006). Továbbá a növekedési elmélet alapján levezethető, hogy a technikai potenciál növelése csak addig a pontig jelent realizált hasznot, amíg bele nem ütköznek a képzettség korlátaiba. Az ütközési ponttól kezdve csak a tudás és technika együttes fejlesztése hozhat eredményt (Kapronczai, 2017).

A szakirodalom alapján tehát elmondható, hogy a tanulás, tudás és kreativitás szorosan kötődik a vállalkozás fejlesztéséhez, illetve hosszú távú fenntartásához. Az újításokkal járó kockázatok azonban komolyan befolyásolhatják a vállalkozás pénzügyi helyzetét. Az is megállapítható, hogy vannak kockázatok, amelyek elkerülhetetlenek, azonban a vállalkozó maga dönt arról, hogy mennyit vállal a vállalkozása érdekében. Egy korábbi kutatás alapján elmondható, hogy a vállalkozók nagyobb arányban vennének részt szerencsejátékban, mint alkalmazott vagy inaktív társaik, ezzel együtt érzékenyebbek is az esélyek változására (Janky-Tóth, 2000; Fodor, 2017). Ebből a kutatásból az is kiderül, hogy minél iskolázottabb valaki, annál nagyobb az esélye, hogy a nagyobb jövedelemmel és egyúttal nagyobb kockázattal járó állást választja.

Kutatásunk céljaként a dunántúli mezőgazdasági vállalkozók újításokra való nyitottságának felderítését tüztük ki. Az irodalmi áttekintés alapján azt a feltételezést szeretnénk alátámasztani, miszerint a fejlett technológiával, valamint magasabb iskolai végzettséggel rendelkező mezőgazdasági vállalkozók nyitottabbak az új fejlesztésekre, mint társaik. A továbbiakban ezen feltételezések alátámasztására, illetve cáfolására keresünk megoldásokat. 


\section{KUTATÁSMÓDSZERTAN}

Kvantitatív vizsgálaton belül kérdőíves felmérés készült a dunántúli térségben, a termőföldek értékelése alapján három értékesnek itélt, illetve három kevésbé értékes termőterülettel rendelkező megyében. A lekérdezés 2018 második felében történt, és a mezőgazdasági vállalkozók mintaelemszáma elérte a 252-t. A megkérdezettek minden esetben mezőgazdaságon belül tevékenykedő vagy annak elemeit aktívan alkalmazó őstermelők, valamint mikro-, kis- és közepes vállalkozások vezetői voltak. A mintavételezés hólabda módszerrel történt. A hipotézisek vizsgálatához a leggyakrabban alkalmazott statisztikai elemző eljárást, a korrelációszámítást választottuk, melyet az SPSS statisztikai programcsomag segítségével hajtottunk végre.

\section{EREDMÉNYEK}

Empirikus kutatásunkon belül a kvantitatív vizsgálathoz köthető kérdőív négy részből épül fel. Első része a tevékenységgel kapcsolatos általános kérdéskör, ezt követi az irányítással kapcsolatos kérdéskör, majd a biztonságra helyeződik a hangsúly kérdések terén, végül a demográfiai kérdések zárják a felmérést. A kérdések közül négy kerül külön kiemelésre, melyek között kapcsolat fedezhetö fel a témánkhoz kötődően.

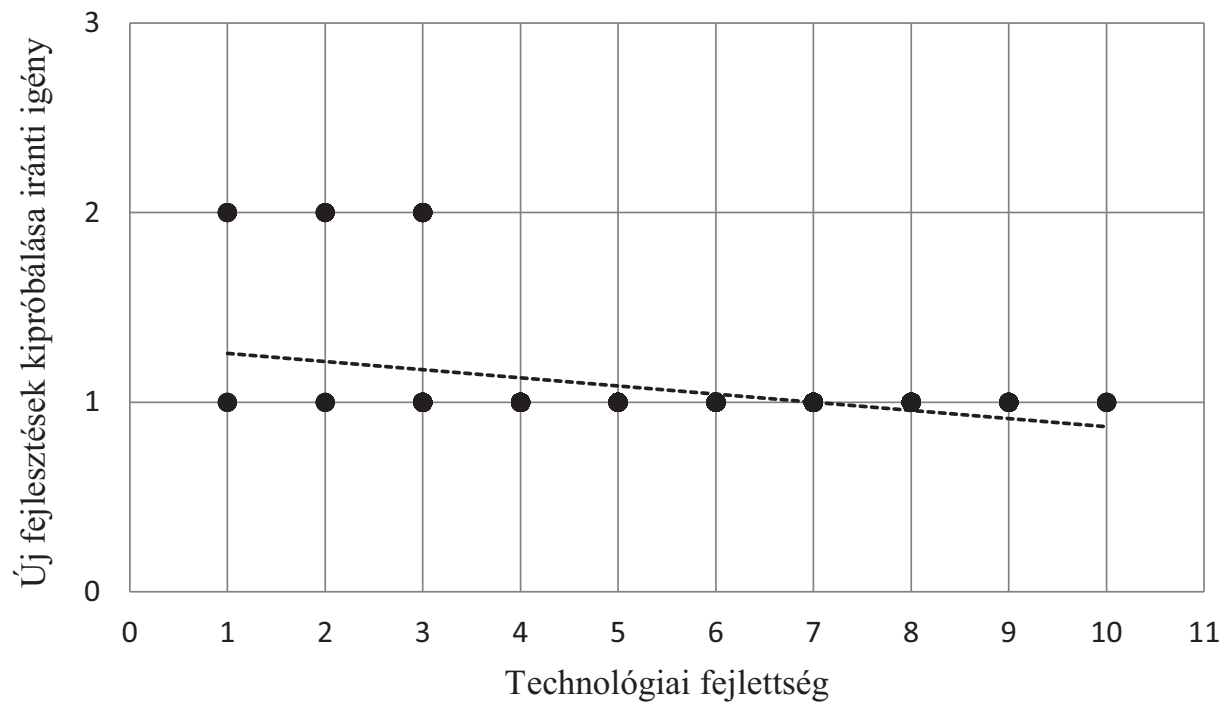

1. ábra. Technológiai fejlettség és új fejlesztések kipróbálása iránti igény összefüggése dunántúli mezőgazdasági vállalkozók körében (saját szerkesztés) 
Az első megállapítás két intervallumskálán értelmezett változó közötti összefüggés vizsgálataként keletkezett, miszerint minél fejlettebb technológiával rendelkezik az adott mezőgazdasági vállalkozó, annál kevésbé fogja kipróbálni az új fejlesztéseket tevékenysége során. A vállalkozóknak a technológiai fejlettségük mellett arra kellett választ adniuk, hogy szívesen próbálják-e ki az új fejlesztéseket tevékenységük során. A változók egyes válaszadókra vonatkozó értékeinek ábrázolása az 1. ábrán látható módon alakul.

A trendvonal mutatja a negatív kapcsolatot a két változó között.

A két változó közötti összefüggést Pearson-féle korrelációs együtthatóval is sikerült kimutatni, ahol $r_{\text {fejlettség, új fejlesztések kipróbálása }}=-0,400$ és $p=0,000$. Tehát teljes bizonyossággal állítható, hogy a két változó között közepesen erős, ellentétes irányultságú kapcsolat mutatható ki. Az összefüggést az 1. táblázat mutatja.

1. táblázat. Technológiai fejlettség és új fejlesztések kipróbálása iránti igény közötti kapcsolat kimutatása korrelációs együttható segítségével

\begin{tabular}{|l|l|c|c|}
\hline \multicolumn{2}{|l|}{} & $\begin{array}{c}\text { Technológiai } \\
\text { fejlettség }\end{array}$ & $\begin{array}{c}\text { Új fejlesztések } \\
\text { kipróbálása iránti igény }\end{array}$ \\
\hline \multirow{4}{*}{$\begin{array}{l}\text { Technológiai } \\
\text { fejlettség }\end{array}$} & Pearson Correlation & 1 & $-0,400$ \\
\cline { 2 - 4 } & Sig. (2-tailed) & & 0,000 \\
\cline { 2 - 4 } & $\mathrm{N}$ & 252 & 252 \\
\hline \multirow{3}{*}{$\begin{array}{l}\text { Új fejlesztések } \\
\text { kipróbálása iránti igény }\end{array}$} & Searson Correlation & $-0,400$ & 1 \\
\cline { 2 - 5 } & Sig. (2-tailed) & 0,000 & \\
\cline { 2 - 5 } & $\mathrm{N}$ & 252 & 252 \\
\hline
\end{tabular}

A táblázatból leolvasható, hogy a két változó közötti kapcsolat negatív és közepesen erős $(0<-0,400<-1)$. Hazai, dunántúli mezőgazdasági vállalkozóink esetében tehát elmondható, hogy minél fejlettebb a technológiája, annál kevésbé szeretné az újdonságokat kipróbálni.

Második megállapításunk a következő változók közötti összefüggés kimutatásának eredménye: szívesen próbálják ki az új fejlesztéseket tevékenységük során, illetve milyen a legmagasabb iskolai végzettségük. A vizsgálat eredménye szerint minél magasabb a végzettsége adott mezőgazdasági vállalkozónak, annál kevésbé próbálja ki az új fejlesztéseket. A változók egyes válaszadókra vonatkozó értékeinek ábrázolása a 2. ábrán látható módon alakul.

A trendvonal mutatja a két változó közötti negatív kapcsolatot. 


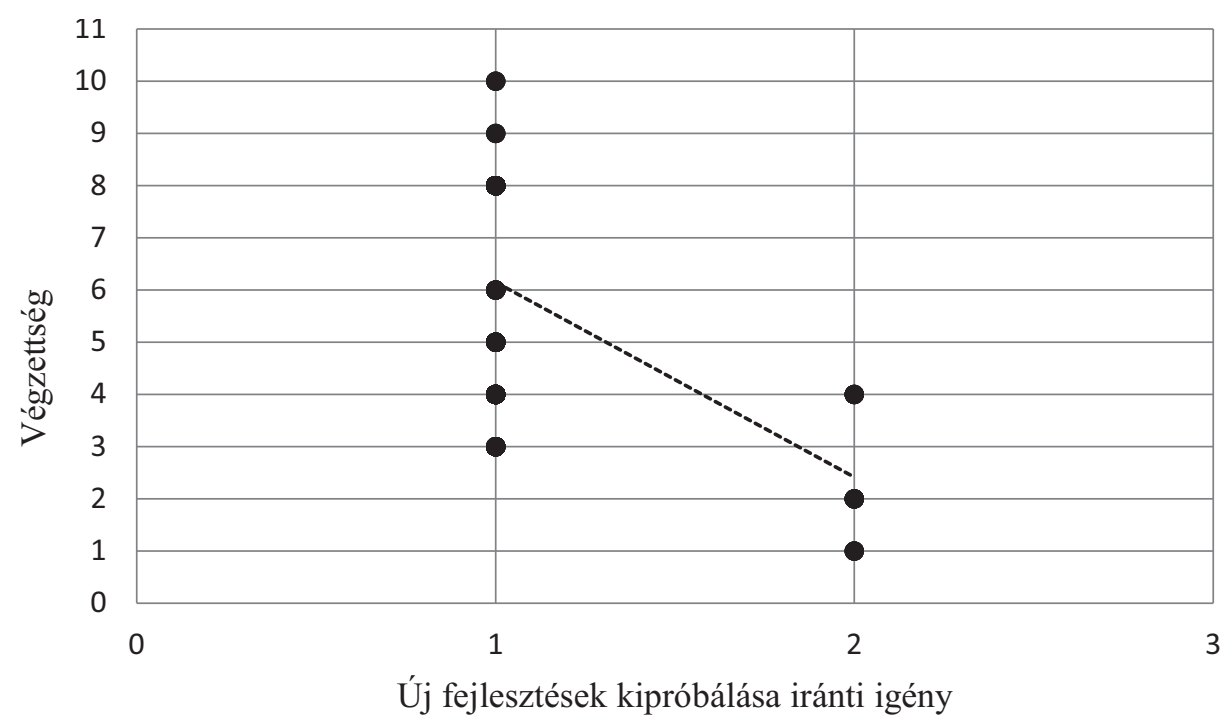

2. ábra. Új fejlesztések kipróbálása iránti igény és végzettség összefüggése dunántúli mezőgazdasági vállalkozók körében (saját szerkesztés)

A két változó közötti összefüggést Pearson-féle korrelációs együtthatóval is sike-

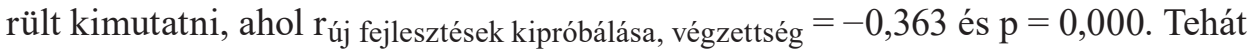
teljes bizonyossággal állítható, hogy a két változó között közepesen erős, ellentétes irányultságú kapcsolat mutatható ki. Az összefüggést a 2. táblázat mutatja.

2. táblázat. Új fejlesztések kipróbálása iránti igény és végzettség közötti kapcsolat kimutatása korrelációs együttható segítségével

\begin{tabular}{|l|l|c|c|}
\hline \multicolumn{2}{|l|}{} & $\begin{array}{c}\text { Új fejlesztések } \\
\text { kipróbálása iránti igény }\end{array}$ & Végzettség \\
\hline \multirow{4}{*}{$\begin{array}{l}\text { Új fejlesztések } \\
\text { kipróbálása iránti igény }\end{array}$} & Pearson Correlation & 1 & $-0,363^{* *}$ \\
\cline { 2 - 4 } & Sig. (2-tailed) & & 0,000 \\
\cline { 2 - 4 } & $\mathrm{N}$ & 252 & 252 \\
\hline \multirow{3}{*}{ Végzettség } & Pearson Correlation & $-0,363^{* *}$ & 1 \\
\cline { 2 - 4 } & Sig. (2-tailed) & 0,000 & \\
\cline { 2 - 5 } & $\mathrm{N}$ & 252 & 252 \\
\hline
\end{tabular}

** A korreláció 0,01 értéktől szignifikáns. 
A táblázatban látható, hogy a két tényező közötti kapcsolat negatív és közepesen erős $(0<-0,363<-1)$, azaz minél magasabb a végzettsége a megkérdezett dunántúli mezőgazdasági vállalkozóinknak, annál kevésbé tartja fontosnak az új fejlesztések kipróbálását.

A kutatás kiinduló hipotézisei közül tehát mindkettőt sikerült megcáfolni, azaz minél fejlettebb a technológiája a mezőgazdasági vállalkozónak, illetve minél magasabb az iskolai végzettsége, annál kevésbé nyitott az új fejlesztések iránt. Mindez ellentmond az irodalomkutatásban kifejtett kutatási eredménynek, miszerint egy bizonyos ponttól a tudás és technika együttes fejlesztése hozhat csak hasznot.

\section{5. ÖSSZEGZÉS}

Kiinduló hipotézisek igazolására elvégzett vizsgálatunk, miszerint a fejlettebb technológia és a magasabb iskolai végzettség további fejlesztésekre motiválná a gazdákat, meglepő eredményeket hozott.

Globálisan azonban a fejlesztéseké és az ezzel együtt járó kockázatoké a főszerep, mivel a tendencia a precíziós gazdaságok felé tolódik, ahol a gazdálkodás a high-tech megoldásokra épül. Természetes velejárója az új technológiáknak a magasabb befektetési költség, ami a kisebb gazdálkodások lemorzsolódását vonhatja maga után.

Azonban a precíziós gazdaságok példája alapján bizonyos, hogy a gazdák akkor válnak leginkább versenyképessé, ha a megszerezhető profi technológia mellé a know-how-t is beszerzik, mivel az eszközök manapság mindenki számára elérhetőek, a technika önmagában nem jelent versenyelőnyt.

A technológián felül továbbá rendkívül fontos az információ és a tudás birtoklása, hogy a vállalkozó mennyire van tisztában a saját termelésének folyamataival, illetve mennyire képes hosszú távra tervezni, meg tudja-e fogalmazni saját stratégiai céljait. Nagyobb gazdaságok esetében a megfelelő szakemberek igénybevétele is növelheti a versenyképességet, ide értve a pénzügyi, a szaktanácsadói, vagy akár a traktorkezelői szakembert is, amennyiben egy automatizált modern eszközre gondolunk. Szükség van továbbá a költségek monitorozására, megfelelö ügyviteli rendszer alkalmazására, képzésekre, digitalizálásra.

Az iskolai végzettségeket vizsgálva a kutatásunk során megkérdezettek több mint harmada föiskolai vagy egyetemi diplomás. A válaszadók ötöde szakmunkásképző bizonyítvánnyal rendelkezik, kicsit kevesebb, mint ötöde pedig szakközépiskolai érettségivel és kiegészítő OKJ-képzéssel. Kettőnek van doktori fokozata, és csak négyen végeztek kizárólag elemi iskolát. Ezek szerint a Dunántúlon jelenleg nem az iskolai végzettség alacsony szintje jelenti a tudás hiányát, csupán a további ismeretek és információk beszerzésének igénye alacsony. Közösségek szervezésével, tanácsadói hálózat kiépítésével talán lehetne javítani a helyzeten. 


\section{IRODALOM}

Benz, M. - Frey, B. S. (2008a): Being Independent Is a Great Thing: Subjective Evaluations of Self-employment and Hierarchy. Economica, 75, 298, 362-383. DOI: 10.1111/j.14680335.2007.00594.x, http://www.econ.uzh.ch/static/wp_iew/iewwp135.pdf

Benz, M. - Frey, B. S. (2008b): The Value of Doing What You Like: Evidence from the Self-employed in 23 Countries. Journal of Economic Behavior and Organization, 68, 445-455. DOI: 10.1016/j.jebo.2006.10.014, https://www.bsfrey.ch/articles/C_617_2008.pdf

Berta O. (2018): Információs technológiák használata a magyar mezőgazdasági vállalkozások menedzsmentjében: avagy egy digitális agrárgazdasági kutatás eredményei, Gazdálkodás, 62, 4, 337-352. DOI: 10.22004/ag.econ.276215, https://ageconsearch.umn.edu/record/276215/?ln=en

Birkner Z. (2017): Települési-térségi identitás. In: Berkesné Rodek N. - Birkner Z. - Ernszt I. et al. (szerk.): Köldökzsinór: A Pannon Városok Szövetségéhez tartozó városok sikerének és megtartó erejének kulcstényezői. Kőszeg: Felsőbbfokú Tanulmányok Intézete, 93-126.

Csótó M. (2017): Informatikai eszközök elterjedtsége és használata a kisgazdaságok irányítóinak információs környezetében. Gazdálkodás, 61, 6, 505-523. DOI: 10.22004/ag.econ.270621, https://ageconsearch.umn.edu/record/270621/?ln=en

Fodor M. (2017): Munkáltatói márkaépités a gyakorlatban. Budapest: Szakmai Konferenciaszervezö Kft.

Janky B. - Tóth I. Gy. (2000): Kockázatvállalásról döntéselméleti megközelítésben. Társadalmi Riport, 2000, 298-322. http://old.tarki.hu/adatbank-h/kutjel/pdf/a852.pdf

Kapronczai I. (2017): A müszaki fejlesztés beruházási háttere és az agrárpolitikai hatások. Gazdálkodás, 61, 3, 187-198. http://www.gazdalkodas.hu/index.php?l=hu\&p=cikk\&cikk_ $\mathrm{id}=1198$

Kazainé Ónodi A. - Kiss J. (2018): Milyen példát mutatnak a sikeres külföldi exportorientált vállalatok az innováció terén a hazai vállalatok számára? Vezetéstudomány, XLIX, 1, 78-86. DOI: 10.14267/VEZTUD.2018.01.08, http://unipub.lib.uni-corvinus.hu/3294/

Keskin, H. (2006): Market Orientation, Learning Orientation, and Innovation Capabilities in SMEs: An Extended Model. European Journal of Innovation Management, 9, 4, 396-417. DOI: 10.1108/14601060610707849, https://www.researchgate.net/publication/242173635_Market_ orientation_learning_orientation_and_innovation_capabilities_in_SMEs_An_extended_model

Kontor E. (2017): A piaci verseny összetevői és a verseny dinamikája. In: Szakály Z (szerk.): Élelmiszer-marketing. Budapest: Akadémiai Kiadó, 190-209. https://mersz.hu/hivatkozas/ dj262em_113

Lukes, M. - Stephan, U. (2017): Measuring Employee Innovation. International Journal of Entrepreneurial Behavior \& Research, 23, 1, 136-158. DOI:10.1108/IJEBR-11-2015-0262, https:// bit.ly/2LMhXAL

McMullen, J. S. - Shepherd, D. A. (2006): Entrepreneurial Action and the Role of Uncertainty in the Theory of the Entrepreneur. Academy of Management Review, 31, 132-152. DOI: 10.5465/ amr.2006.19379628, https://www.researchgate.net/publication/255606121_Entrepreneurial_ Action_and the_Role_of_Uncertainty_in the Theory_of_Entrepreneur

Noszkay E. (2017): Tapasztalatok a családi vállalkozások átörökítésének dilemmái kapcsán. Vezetéstudomány, XLVIII, 6-7, 64-72. http://unipub.lib.uni-corvinus.hu/2958/

Nótári M. - Berdeb Cs. - Ferencz Á. (2013): Human Resources Management and Education in Hungarian Agriculture. Procedia - Social and Behavioral Sciences, 81, 632-637. DOI: 10.1016/j. sbspro.2013.06.488, https://www.researchgate.net/publication/270849658_Human_Resources_Management_and_Education_in_Hungarian_Agriculture 
Parker, S. C. (2004): The Economics of Self-employment and Entrepreneurship. Cambridge University Press

Péter E. (2018): Vezetöi lábnyom: A vezetö szerepe és a munkaerö motivációs lehetőségei a vállalati kultúrában. Veszprém: Pannon Egyetemi Kiadó, https://www.researchgate.net/publication/334761573_Peter_Erzsebet_PhD_VEZETOI_LABNYOM_A_vezeto_szerepe_es_a_ munkaero_motivacios_lehetosegei_a_vallalati_kulturaban

Sarooghi, H. - Libaers, D. - Burkemper, A. (2015): Examining the Relationship between Creativity and Innovation: A Meta-Analysis of Organizational, Cultural, and Environmental Factors. Journal of Business Venturing, 30, 5, 714-731. DOI: 10.1016/j.jbusvent.2014.12.003, https:// daneshyari.com/article/preview/1019333.pdf

Schumpeter, Joseph A. (1934): The Nature and Necessity of a Price System. In: Harris, S. E. - Bernstein, E . M. (eds.): Economic Reconstruction. New York-London: McGraw-Hill

Shir, N. - Nikolaev, B. N. - Wincent, J. (2018): Entrepreneurship and Well-being: The Role of Psychological Autonomy, Competence, and Relatedness. Journal of Business Venturing. DOI: 10.1016/j.jbusvent.2018.05.002, https://www.researchgate.net/publication/325049358_Entrepreneurship_and_well-being_The_role_of_psychological_autonomy_competence_and_relatedness 